ACTA MYCOLOGICA

Vol. 44 (2): 249-257

2009
Dedicated to Professor Krystyna Czyżewska

in honour of 40 years of her scientific activity

\title{
Additions to the biota of lichenized fungi of Poland
}

\author{
ADAM FLAKUS ${ }^{1}$ and MARTIN KUKWA ${ }^{2}$ \\ ${ }^{1}$ Laboratory of Lichenology, W. Szafer Institute of Botany, Polish Academy of Sciences \\ Lubicz 46, PL-31-512 Kraków, a.flakus@botany.pl \\ ${ }^{2}$ Department of Plant Taxonomy and Nature Protection, University of Gdańsk \\ Al. Legionów 9, PL-80-441 Gdańsk, dokmak@univ.gda.pl
}

Flakus A., Kukwa M.: Additions to the biota of lichenized fungi of Poland. Acta Mycol. 44 (2): 249-257, 2009.

New records of five lichenized fungi from Poland are provided. Hypotrachyna afrorevoluta, Lecanora quercicola, Rhizocarpon superficiale and Strigula ziziphi are new to Poland. Of these, Strigula ziziphi is reported also as new to Central Europe and Hypotrachyna afrorevoluta as new to the Carpathians. Additionally, Thelenella muscorum var. octospora is recorded from its second locality in Poland as new to the Polish Carpathians. Hypostictic acid chemosyndrome has been noticed for the first time in European (Poland) and South American (Bolivia) populations of Rhizocarpon superficiale.

Key words: chemotaxonomy, neglected lichens, Hypotrachyna, Lecanora, Rhizocarpon, Strigula, Thelenella

\section{INTRODUCTION}

Currently known lichen biota of Poland include about 1600 lichens (Fałtynowicz 2003) and 222 lichenicolous fungi and myxomycetes (Czyżewska, Kukwa 2009), and can be considered as rather rich and well investigated. However, the country is also still non-uniformly investigated, and several additional species, including taxa new to science, can be found, what has been recently demonstrated by several authors (Cykowska, Flakus 2005; Kukwa, Diederich 2005; Czarnota 2007; Flakus 2007; Kukwa, Kubiak 2007; Czarnota, Kukwa 2008; Kossowska 2008; Motiejūnaitė, Czyżewska 2008; Motiejūnaitė, Kukwa 2008; Kukwa, Jabłońska 2009; Zhurbenko et al. 2009). In the paper we present further four records of lichenized fungi new to Poland, of which Strigula ziziphi is new to Central Europe, and Hypotrachyna afrorevoluta and Thelenella muscorum var. octospora are respectively new to the Carpathians and the Polish Carpathians. Additionally hypostictic acid is reported for the first time from European and South American specimens of Rhizocarpon superficiale. 


\section{MATERIAL AND METHODS}

The present study is based on the specimens deposited in following lichen herbaria: B, KRAM, LG, LPB, UGDA. The anatomy and morphology of the material were studied by traditional tools used in lichenology. Secondary metabolites were identified by thin layer chromatography (TLC) in solvents A, B and/or C according to the methods of Orange et al. (2001). Localities of all Polish examined specimens are mapped according to the modified ATPOL grid square system (Cieśliński, Fałtynowicz 1993; Kukwa et al. 2002).

\section{RESULTS AND DISCUSSION}

Hypotrachyna afrorevoluta (Krog \& Swinscow) Krog \& Swinscow, Lichenologist 19: 420 (1987).

Syn. Parmelia afrorevoluta Krog \& Swinscow, Norweg. J. Bot. $26: 22$ (1979); Parmelinopsis afrorevoluta (Krog \& Swinscow) Elix \& Hale, Mycotaxon 29: 242 (1987).

Morphology and chemistry. The species has foliose, grey or grey-green, rather compact thallus, up to ca 4 in diam., lobes are rounded, separate, but more or less overlapping towards the center, with smooth surface, and sparsely ciliate margin. Soredia are produced in laminal or submarginal soralia formed from pustules. Lower surface is usually shiny and brown, dark brown to almost black up to the margin. The species produces atranorin in the cortex and gyrophoric (major) and lecanoric (minor) acids together with related accessory substances (in trace amounts) in medulla (Swinscow, Krog 1988; Ertz et al. 2008). The cortex is K+ yellow, whereas the medulla reacts $\mathrm{C}+$ pink-red and $\mathrm{KC}+$ red.

Notes. H. afrorevoluta is very similar to $H$. revoluta (Flörke) Hale, and all Polish herbarium specimens were found under the latter name. Both taxa are sorediate and produce the same lichen substances, but they differ mainly in the formation of soralia. In $H$. afrorevoluta they are formed from laminal or submarginal pustules, which break and start to produce granular soredia, whereas in $H$. revoluta soralia develop apically on the upper surface of relatively large and elongated lobes, and soredia are more farinose than in $H$. afrorevoluta. According to Ertz et al. (2008) they can be also distinguished by the colour of lower surface of young lobes; it is brown to dark brown or blackish and shiny in $H$. afrorevoluta, whereas in $H$. revoluta it is usually pale brown and matt.

In so far studied Polish material the soralia were well developed in few specimens of both taxa, and thus the determination of them was not difficult. Some thalli were covered with dust or algae, deformed, degenerated and probably collected from polluted or disturbed ecosystems, and then soralia were often badly developed (i.e. some produced at the apices, but some formed also laminally, or very few young soralia were present). In such cases, we used the colour of lower cortex for the determination of species, and in these samples it was rather pale brown at the margin of lobes, and thus suggesting $H$. revoluta; however it was not matt, but shiny. We attributed 
those specimens to $H$. revoluta, but with a hesitation. Their true identity may become more clear when the morphology of all Polish collections is studied. It was already noted by Ertz et al. (2008), that specimens can not be always determined.

Habitat. The species is mainly corticolous on bark of many tree species (Swinscow, Krog 1988; Ertz et al. 2008), but in Poland one specimen was also found on rock. Two specimens from northern Poland were found in humid forests, but habitat details were missing on remaining labels.

General distribution. $H$. afrorevoluta is widely distributed in the world. Originally it was described from Africa (Krog, Swinscow 1979; Swinscow, Krog 1988), but later it was reported from Belgium, France, British Isles, Germany, Luxembourg, the Netherlands, Norway, Portugal and Switzerland in Europe (Santesson 1993; Masson 2005; Hitch 2007; Spier et al. 2007; Dolnik et al. 2008; Ertz et al. 2008), China in Asia (Chen et al. 2003), North America (Knudsen, Lendemer 2005; Lendemer 2006) and South America (Adler, Elix 1992).

Distribution in Poland. H. afrorevoluta is reported here for the first time from Poland and the Carpathians. It can be rather widely distributed in the country as localities of this lichen are known from northern and southern part of Poland. Possibly it can be more common than $H$. revoluta, similar as in Belgium, northern France, Luxembourg and the Netherlands (Spier et al. 2007; Ertz et al. 2008).

Specimens eXaminated. Poland. Ac 34 - Wybrzeże Słowińskie coast, Mierzeja Sarbska split, forest section No. 14Dm, black alder forest, on Alnus glutinosa, 4 Oct. 1998, leg. W. Fattynowicz (UGDA-L 13353). Bd 53 - Pojezierze Iławskie lakeland, E of Szadowo village, Liwa river valley, N bank of the river, $53^{\circ} 46^{\prime} 20^{\prime} \mathrm{N}, 19^{\circ} 03^{\prime} 28^{\prime \prime} \mathrm{E}$, hornbeam-lime forest, on Alnus glutinosa, 16 April 2006, leg. M. Kukwa 4946 (UGDA-L 13528). Fg 01 - Roztocze Środkowe, Kosobudy forest inspectorate, forest district Czerkies, ca $50^{\circ} 35^{\prime} \mathrm{N}, 23^{\circ} 01^{\prime} \mathrm{E}$, the edge of the forest, on Fagus sylvatica, 30 June 1952, leg. Z. Tobolewski (UGDA-L 4480). Gf 10 - Beskid Niski Mts., Diabli Kamień rock near Folusz village, on rock, ca 1954, leg. T. Sulma (UGDA-L 12155).

Lecanora quercicola Coppins \& P. James, Lichenologist 11: 145 (1979).

Morphology and chemistry. L. quercicola belongs to L. saligna-group, and is characterized by apothecia with a pale yellowish, corticate, lecanorine margin, pale yellowish, to brown and \pm pruinose disc, yellow-brown to olive brownish epihymenium not reacting with $\mathrm{N}$, ellipsoid ascospores $(8.6-10 \times 4.3-4.8 \mu \mathrm{m})$, weakly curved, luniform, non-septate macroconidia measuring 8.5-9.5 $\times(2.5-) 2.7-3.0(-3.2) \mu \mathrm{m}$, and the production of isousnic acid as a major secondary metabolite (Coppins, James 1979; Boom, Brand 2008).

Polish specimen matches this characteristic well, except the small difference in the size of macroconidia, which are (8-)8.5-9 $\times 2.5-3.0 \mu \mathrm{m}$.

Notes. L. quercicola is very similar to L. saligna (Schrad.) Zahlbr. s.str. Both taxa have almost the same morphology, size of ascospores, and chemistry, but they predominantly differ in dimensions of macroconidia; they are 6.0-8.1 $\times 2.0-2.4 \mu \mathrm{m}$ in L. saligna, whereas 8.5-9.5 × 2.7-3.0 $\mu \mathrm{m}$ in L. quercicola (Boom, Brand 2008).

When we revised the material of both taxa from UGDA, we found, that pycnidia containing macroconidia were usually difficult to find on most thalli. Pycnidia are very small and often pale brown, and they can be mistaken for very young apothecia or dust impregnation. Sometimes, pycnidia with microconidia were much more abundant than those with macroconidia. Therefore, several squash preparations are advised to be made for the identification of single specimen. Some specimens did 
not posses conidiomata with macroconidia at all, and such material could not have been determined.

Habitat. L. quercicola grows on wood and bark of trees (Quercus spp. and Olea europaea) in open places in woodlands (Coppins, James 1979; Boom, Brand 2008). In Poland it was found on wood of fallen decorticated branch (probably Salix acutifolia) on grey sand dune. The place was well lit and sheltered from wind.

General distribution. The species is known only from Europe and so far it has been reported from France, Germany, Great Britain, Portugal and Spain (Coppins, James 1979; Boom, Brand 2008).

Distribution in Poland. L. quercicola is here reported as new to Poland. Until know it has been found only by the sea shore in one locality during the inventory of the lichen biota of 'Helskie Wydmy' nature reserve. The revision of material $L$. saligna-group deposited in UGDA (ca 30 vouchers) did not yield any additional specimen of L. quercicola.

Specimen examinated. Poland. Ad 51 - Mierzeja Helska split, 'Helskie Wydmy' nature reserve, Jastarnia forest division, $54^{\circ} 39^{\prime} 18^{\prime \prime} \mathrm{N}, 18^{\circ} 46^{\prime} 42^{\prime \prime} \mathrm{E}$, sand dunes, on wood of fallen tree branch, 12 May 2009, leg. M. Kukwa 7388 \& I. S. Stepanchikova (UGDA).

Rhizocarpon superficiale (Schaer.) Vain., Acta. Soc. Fauna Fl. Fenn. 53 (1): 319 (1922).

Syn. Lecidea superficiale Schaer., Lich. Helvet. Spicil. [part 3]: 125 (1822).

Morphology and chemistry. $R$. superficiale is characterized by crustose, areolate, epruinose thallus, and usually well developed black prothallus. Areoles are bright yellow to whitish yellow, with smooth or often scabrose surface. Medulla is white and reacts $\mathrm{I}-, \mathrm{K}+$ yellow, $\mathrm{PD}+$ orange. The species produces rhizocarpic, hypostictic, stictic, and/or norstictic acids (Geyer et al. 1984; Feuerer, Timdal 2004). Apothecia are black, epruinose, usually angular, plane to weakly convex, 0.5-1(2) mm in diam., with black, often persistent margin. Asci are 8-spored, and ascospores are 1-septate, dark green-brown when mature, 14-18 × 6-8 um (Runemark 1956; Wirth 1995; Feuerer, Timdal 2004; Fletcher et al. 2009).

Notes. $R$. superficiale can be easily distinguished from other yellow, morphologically similar species by 1-septate, small ascospores and the presence of norstictic, stictic or hypostictic acids as major secondary compounds (Wirth 1995; Feuerer, Timdal 2004; Fletcher et al. 2009).

This species is diverse in regards of chemical compounds. In European populations either stictic or norstictic acid have been recorded as a main substances, whereas in North American material hypostictic and stictic acids, with norstictic acid as a minor compound (Geyer et al. 1984; Wirth 1995; Feuerer, Timdal 2004). In specimens examined by us from Poland and Bolivia hypostictic and stictic acids were detected as a major compounds, together with related additional substance in small amount (possibly cryptostictic acid). It is the first record of this substance from European and South American populations of $R$. superficiale. The norstictic acid was not confirmed from Polish specimens neither by both TLC analysis and microchemical reactions under the microscope with $\mathrm{KOH}$ solution (characteristic red, needle-shaped crystals were not observed).

Habitat. The species occurs on siliceous, exposed rocks in high mountains or cool areas (Runemark 1956; Wirth 1995; Feuerer, Timdal 2004; Fletcher et al. 2009). 
Three Polish specimens were collected from vertical, south exposed granite rock in the subnival belt.

General distribution. The species is a bipolar, widespread species, known from Africa, Antarctica, Asia, Australasia, Europe, North America and South America (Runemark 1956; Feuerer, Timdal 2004; Olech 2004; Lisická 2005; Fletcher et al. 2009).

Distribution in Poland. $R$. superficiale is reported in this paper for the first time from Poland. So far it has been found only in two localities in Tatra Mts. at the altitude above $2300 \mathrm{~m}$.

Specimens examinated. Poland. Ge 60 - Western Carpathians, High Tatra Mts., Mięguszowiecki Szczyt Mt., 49 ${ }^{\circ} 11^{\prime} 13^{\prime \prime} \mathrm{N}, 20^{\circ} 03^{\prime} 34^{\prime \prime} \mathrm{E}, 2438 \mathrm{~m}$, subnival belt, on vertical granite rock, 9-17 Aug. 2003, leg. A. Flakus 1500, 2007 (KRAM); Pośredni Mięguszowiecki Szczyt Mt., 49¹1’04”N, 2003'50”'E, alt. 2360 m, subnival belt, on vertical granite rock, 3 Aug. 2003, leg. A. Flakus 1213 (KRAM).

Additional specimens examinated. Bolivia. Dept. La Paz, Prov. Murillo, upper part of valley under Mt. Chockaltaya, $16^{\circ} 20^{\prime} 41^{\prime \prime S}, 68^{\circ} 08^{\prime} 10^{\prime \prime E}$, alt. 4980 m, on siliceous rock, 9 Dec. 2004, leg. A. Flakus 4461 (B, KRAM, LPB).

Strigula ziziphi (A. Massal.) Cl. Roux \& Sérus., Biblioth. Lichenol. 90: 55 (2004).

Syn. Sagedia ziziphi A. Massal., Miscellanea lichenologica: 30 (1856); Strigula mediterranea Etayo, Lichenologist 25: 258 (1993).

Morphology. S. ziziphi has thin, in most parts endophloedic thallus in shades of brown, Trentepohlia as photobiont, black perithecia $(0.2-) 0.3-0.4(-0.5) \mathrm{mm}$ in diam., hamathecium consisting of mostly simple, only rarely branched and anastomosing paraphysoids and claviform asci with biseriate spores; spores are 1-septate, distinctly constricted at the septa and early breaking into two parts, specially at the ascus dehiscence, and measure (18-)19.5-27(28) $\mu \mathrm{m}$. The species develops two types of $c o-$ nidia, macro- and microconidia, which are produced in macro- and micropycnidia, respectively. Macroconidia are 1-septate, guttulate, often with gelatinous (mucoid) appendages, and measure (8-)9-11(-11.5) × (2.5-)3-4(-4.5) $\mu \mathrm{m}$; macropycnidia are $0.12-0.2(-0.3) \mathrm{mm}$ in diam. Microconidia are fusiform or subfusiform, $2.5-5 \times 1-2$ $\mu \mathrm{m}$; micropycnidia are 0.1-0.18 mm (Etayo 1993, sub S. mediterranea; Roux, Sérusiaux 2004). In Polish material only macropycnidia with macroconidia were found.

Notes. So far this species has not been found with perithecia in Poland, and therefore it can be very easily overlooked in the country; difficulties may also appear in the identification of such material; however up to our knowledge, there is no other corticolous lichen species with 1-septate macroconidia as described above and Trentepohlia as photobiont.

S. affinis (A. Massal.) R. C. Harris is the only other corticolous member of the genus known from Poland (Fałtynowicz 2003). It can also develop sterile thalli with macropycnidia, but it differs in 3-septate macroconidia (Roux, Sérusiaux 2004).

In Poland $S$. ziziphi can be also confused with a common Anisomeridium polypori (Ellis \& Everh.) M. E. Barr and rare A. ranunculosporum (Coppins \& P. James) Coppins [syn. Arthopyrenia ranunculospora Coppins \& P. James], Arthopyrenia cerasi (Schrad.) A. Massal. and A. cinereopruinosa (Schaer.) Körb. They all differ in pycnidial and conidial characters. Anisomeridium polypori has conical macropycnidia, smaller macroconidia $(3.5-4.5 \times 1.8-3 \mu \mathrm{m})$ extruded as a white cirrus from ostiolum; micropycnidia are \pm immersed, globose and up to $0.1 \mathrm{~mm}$ in diam., with small, 2-3 × 1-1.3 um microconidia (Coppins et al. 2009). In A. ranunculosporum 
macropycnidia and micropycnidia are smaller (respectively up to $0.12 \mathrm{~mm}$, and up $0.06 \mathrm{~mm}$ in diam.), macroconidia have similar size to those of Strigula ziziphi, but are predominantly non-septate, and microconidia are bacilliform and narrower (0.5-0.8 $\mu \mathrm{m}$ in width) (Coppins et al. 2009). Both, Arthopyrenia cerasi and A. cinereopruinosa are not lichenized. $A$. cerasi has 3 -septate macroconidia, which are longer $(11-13 \mu \mathrm{m})$, but narrower $(2-2.5 \mu \mathrm{m})$ than in $S$. ziziphii; micronidia are much longer and narrower $(9-14 \times 0.8 \mu \mathrm{m})$. In $A$. cinereopruinosa macroconidia are simple $(8-11 \times 1.8-2.2 \mu \mathrm{m})$ and microconidia mostly longer and wider $(4.7-6 \times 1 \mu \mathrm{m})$ (Coppins, Orange 2009).

Habitat. The species $S$. ziziphi grows on different types of trees, and at least in Iberian Peninsula it is photophilous and somewhat nitrophilous lichen growing in rather humid places (Etayo 1993; Roux, Sérusiaux 2004). In Poland it was found on bark of willow in open, but humid place by the river.

General distribution. The species has been so far reported from Croatia, France, Greece, Italy, the Netherlands, Portugal, Switzerland, Ukraine (Crimean Peninsula), and outside Europe only in Canary Islands (Etayo 1993, sub S. mediterranea; Scheidegger et al. 2002, sub S. mediterranea; Roux, Sérusiaux 2004).

Distribution in Poland. S. ziziphi it is reported for the first time from Poland and Central Europe. Its finding in this regions appears rather unexpected, but the species can develop sterile thalli with macropycnidia only (as in Polish material), therefore it can be easily overlooked and its true distribution may have not yet been determined.

Specimen examinated. Poland. Ac 51 - Wybrzeże Słowińskie coast, Smołdzino village, by Łupawa river, on Salix sp., 19 March 1995, leg. W. Fattynowicz, det. E. Sérusiaux (UGDA-L 10053, dupl. LG).

Thelenella muscorum var. octospora (Nyl.) Coppins \& Fryday, Lichenologist 36 (2): 91 (2004).

Syn. Verrucaria muscicola var. octospora Nyl. in Ohlert, Schriften Königl. Phys.-Ökon. Ges. Königsberg 11: 43 (1870); Chromatochlamys muscorum var. octospora (Nyl.) H. Mayrhofer \& Poelt, Herzogia 7 (1-2): 37 (1985).

Morphology. T. muscorum var. octospora is a terricolous or epiphytic species, characterized by thin, whitish or pale brown crustose thallus, with chlorococcoid photobiont, and small, rounded or broadly pyriform, dark brown perithecia, ussually immersed in substratum, $0.3-0.6 \mathrm{~mm}$ in diam. It has persistent, branched and anastomozed paraphysoids, functionally bitunicate, thick walled, Thelenella-like asci, with 6-8 ascospores; ascospores are thin-walled, muriform, elongate-ellipsoid and colourless, ca 40-60 × 12-20 $\mu \mathrm{m}$ (Mayrhofer, Poelt 1985; Fryday, Coppins 2004; Orange et al. 2009).

Notes. T. muscorum var. octospora is very similar to T. muscorum var. muscorum, which differs by 2-4-spored asci and bigger ascospores $(60-110 \times 20-27 \mu \mathrm{m})$ (Mayrhofer, Poelt 1985). T. muscorum var. octospora can be also confused with Strigula confusa Fryday, Coppins \& Comminis, superficially similar species that was recently described from British Isles, but the latter taxon differs in black, globose perithecia, other ascus type, Trentepohlia photobiont and smaller ascospores (Fryday, Coppins 2004).

Habitat. This lichen occurs mainly on bryophytes, plant debris, basic-barked trees and rarely on soil, basic rocks or lichen thalli (Mayrhofer, Poelt 1985; Fryday, Coppins 2004; Orange et al. 2009). In Poland it was discovered on plant debris in mylonitized area of the subnival belt in the Tatra Mts. 
General distribution. T. muscorum var. octospora is known from British Isles, Denmark, Germany, Fennoscandia (Sweden and Norway), Greenland and North America (Mayrhofer, Poelt 1985; Alstrup 1993, 2004; Santesson et al. 2004; Esslinger 2009).

Distribution in Poland. The taxon was originally described in 1870 as Verrucaria muscicola var. octospora from northern Poland (Mayrhofer, Poelt 1985), however, it has not been included in the last checklist of lichen biota. Here we report its second Polish locality from Tatra Mts., which is also the first record for the Polish Carpathians.

Specimen examinated. Poland. Ge 60 - Szpiglasowa Przełęcz pass, 49¹1'53”N, 2002’34”E, 2105 m, subnival belt, on plant debris in mylonitized area, 24 Aug. 2004, leg. A. Flakus 3376 (KRAM).

Acknowledgement. We are very grateful to Professor Emmanuël Sérusiaux (Liège) for the determination of Strigula ziziphi. It is our pleasure and honor to dedicate this paper to Professor Krystyna Czyżewska (Łódź) on the occasion of her anniversary.

\section{REFERENCES}

Adler M. T., Elix J. A. 1992. New records of Hypotrachyna and Parmelinopsis lichens (Ascomycotina, Parmeliaceae) from northwest and central Argentina. Mycotaxon 43: 283-288.

Alstrup V. 1993. News on lichens and lichenicolous fungi from the Nordic countries. Graphis Scripta 5 (2): 96-104.

Alstrup V. 2004. New records in distribution of lichens and lichenicolous fungi. Graphis Scripta 16 (2): $46-57$.

Boom van den P., Brand 2008. Some new Lecanora species from western and central Europe, belonging to the $L$. saligna group, with notes on related species. Lichenologist 40 (6): 465-497.

Chen J.-B., Wang S. L., Elix J. A. 2003. Parmeliaceae (Ascomycota) lichens in China's mainland I. The genera Canomaculina, Parmelina, Parmelinella and Parmelinopsis. Mycotaxon 86: 19-29.

Cieśliński S., Fałtynowicz W. 1993. Note from editors. (In:) S. Cieśliński, W. Fałtynowicz (eds). Atlas of the geographical distribution of lichens in Poland. 1. W. Szafer Institute of Botany, Polish Academy of Sciences, Kraków: 7-8.

Coppins B. J., James P. W. 1979. New or interesting British lichens IV. Lichenologist 11 (2): 139-179.

Coppins B. J., James P. W., Orange A. 2009. Anisomeridium (Müll. Arg.) M. Choisy. (1928). (In:) C. W. Smith, A. Aptroot, B. J. Coppins, A. Fletcher, O. L. Gilbert, P. W. James, P. A. Wolseley (eds). The lichen flora of Great Britain and Ireland. Natural History Museum Publications, London: 148-150.

Coppins B. J., Orange A. 2009. Arthopyrenia A. Massal. (1852). (In:) C. W. Smith, A. Aptroot, B. J. Coppins, A. Fletcher, O. L. Gilbert, P. W. James, P. A. Wolseley (eds). The lichen flora of Great Britain and Ireland. Natural History Museum Publications, London: 171-176.

Cykowska B., Flakus A. 2005. Epigloea medioincrassata (Epigloeaceae, non-lichenized Ascomycota), a species new to Poland. Polish Bot. J. 50 (2): 233-234.

Czarnota P. 2007. The lichen genus Micarea (Lecanorales, Ascomycota) in Poland. Polish Bot. Stud. 23: $1-199$.

Czarnota P., Kukwa M. 2008. Contribution to the knowledge of some poorly known lichens in Poland. I. The genus Absconditella. Folia Cryptog. Estonica 44: 1-7.

Czyżewska K., Kukwa M. 2009. Lichenicolous fungi of Poland. A catalogue and key to species. (In:) Z. Mirek (ed.). Biodiversity of Poland. 11. W. Szafer Institute of Botany, Polish Academy of Sciences, Kraków, 133 pp.

Dolnik C., Abel H., Bruyn, de U., Dort van K., Gnüchtel A., Neumann P., Stolley G., Zimmeret D. 2008. Lecanora zosterae und andere interessante Flechtenfunde aus Schleswig-Holstein. Kiel. Not. Pflanzenkd. 36: 9-23.

Ertz D., Diederich P., Brand A. M., Boom van den P., Sérusiaux E. 2008. New or interesting lichens and lichenicolous fungi from Belgium, Luxembourg and northern France. XI. Bull. Soc. Naturalistes Luxemb. 109: 35-51. 
Esslinger T. L. 2009. A cumulative checklist for the lichen-forming, lichenicolous and allied fungi of the continental United States and Canada. Available at http://www.ndsu.nodak.edu/instruct/esslinge/ chcklst/chcklst7.htm (First Posted 1 December 1997, Most Recent Update 27 August 2009), date of exploration: 5 September 2009.

Etayo J. 1993. Strigula mediterranea, a new name for the forgotten lichen Porina schizospora. Lichenologist 25 (3): 257-260.

Fałtynowicz W. 2003. The lichens, lichenicolous and allied fungi of Poland - an annotated checklist. (In:) Z. Mirek (ed.). Biodiversity of Poland. 6. W. Szafer Institute of Botany, Polish Academy of Sciences, Kraków, 435 pp.

Feuerer T., Timdal E. 2004. Rhizocarpon. (In:) T. H. N. Nash III, B. D. Ryan, P. Diederich, C. Gries, F. Bungartz (eds). Lichen Flora of the Greater Sonora Desert Region. II (most of microlichens, balance of the macrolichens, and the lichenicolous fungi). Lichens Unlimited, Arizona State University, Tempe, Arizona, 456-466.

Flakus A. 2007. Lichenized and lichenicolous fungi from mylonitized areas of the subnival belt in the Tatra Mountains (Western Carpathians). Ann. Bot. Fenn. 44: 427-449.

Fletcher A., Gilbert O. L., Clayden S., Fryday A. M. 2009. Rhizocarpon Ramond ex DC. (1805). (In:) C. W. Smith, A. Aptroot, B. J. Coppins, A. Fletcher, O. L. Gilbert, P. W. James, P. A. Wolseley (eds). The lichen flora of Great Britain and Ireland. Natural History Museum Publications, London, 792-808.

Fryday A. M., Coppins B. J. 2004. A reassessment of the genera Chromatochlamys and Thelenella, and a new species of Strigula from the British Isles. Lichenologist 36 (2): 89-95.

Geyer M., Feuerer T., Feige G. B. 1984. Chemie und Systematik in der Flechtengattung Rhizocarpon: Hochdruckflüssigkeitschromatographie (HPLC) der Flechten-Sekundärstoffe der Rhizocarpon superficiale-Gruppe. Pl. Syst. \& Evol. 145: 41-54.

Hitch C. 2007. New, rare and interesting lichens. Brit. Lich. Soc. Bull. 100: 72-90.

Knudsen K., Lendemer J. C. 2005. Changes and additions to the North American lichen flora. IV. Mycotaxon 93: 289-295.

Kossowska M. 2008. Pertusaria lactescens (lichenized Ascomycota, Pertusariaceae), a lichen species new to central Europe. Polish Bot. J. 53 (1): 69-70.

Krog H., Swinscow T. D. V. 1979. Parmelia subgenus Hypotrachyna in East Africa. Norweg. J. Bot. 26: $11-43$.

Kukwa M., Diederich P. 2005. Monodictys epilepraria, a new species of lichenicolous hyphomycetes on Lepraria. Lichenologist 37: 217-220.

Kukwa M., Jabłońska A. 2009. New records of two crustose sorediate lichens from central Europe. Mycotaxon 107: 375-381.

Kukwa M., Kubiak D. 2007. Six sorediate crustose lichens new to Poland. Mycotaxon 102: 155-164.

Kukwa M., Motiejūnaite J., Rutkowski P., Zalewska A. 2002. New or interesting records of lichenicolous fungi from Poland. Part I. Herzogia 15: 129-139.

Lendemer J. C. 2006. Hypotrachyna afrorevoluta discovered in central California. Bull. California Lich. Soc. 13 (1): $1-2$.

Lisická E. 2005. The lichens of the Tatry Mountains. VEDA the Publishing House of the Slovak Academy of Sciences, Bratislava, 439 pp.

Masson D. 2005. Taxonomie, écologie et chorologie des espèces françaises des genera Hypotrachyna et Parmelinopsis (Ascomycota lichénisés, Parmeliaceae). Cryptog., Mycol. 26 (3): 205-263.

Mayrhofer H., Poelt J. 1985. Die Flechtengattung Microglaena sensu Zahlbruckner in Europa. Herzogia 7: 13-79.

Motiejūnaitė J., Czyżewska K. 2008. Additions to the biota of lichens and lichenicolous fungi of Poland, with a note on Lecania prasinoides in estern and central Europe. Polish Bot. J. 53 (2): 155-162.

Motiejūnaite J., Kukwa M. 2008. Pronectria minuta, a new lichenicolous ascomycete from Poland and Russia. Mycotaxon 104: 229-234.

Olech M. 2004. Lichens of King George Island, Antarctica. Institute of Botany, Jagiellonian University, Kraków, 391 pp.

Orange A., James P. W., White F. J. 2001. Microchemical methods for the identification of lichens. British Lichen Society, London, 101 pp. 
Orange A., Purvis O. W., James P. W. 2009. Thelenella Nyl. (1855). (In:) C. W. Smith, A. Aptroot, B. J. Coppins, A. Fletcher, O. L. Gilbert, P. W. James, P. A. Wolseley (eds). The lichen flora of Great Britain and Ireland. Natural History Museum Publications, London, 877-879.

Roux C., Sérusiaux E. 2004. Le genre Strigula (Lichenes) en Europe et en Macaronésie. Biblioth. Lichenol. 90: 1-96.

Runemark H. 1956. Studies in Rhizocarpon. I. Taxonomy of the yellow species in Europe. Opera Botanica $2(1): 1-152$.

Santesson R. 1993. The lichens and lichenicolous fungi of Sweden and Norway. SBT-förlaget, Lund, 240 pp.

Santesson R., Moberg R., Nordin A., Tønsberg T., Vitikainen O. 2004. Lichen-forming and lichenicolous fungi of Fennoscandia. Museum of Evolution, Uppsala University, Uppsala, 359 pp.

Scheidegger C., Clerc P., Dietrich M., Frei M., Groner U., Keller C., Roth I., Stofer S., Vust M. 2002. Rote Liste der gefährdeten Arten der Schweiz: Baum- und erdbewohnende Flechten. BUWAL-Reihe Vollzug Umwelt, Bundesamt für Umwelt, Wald und Landschaft BUWAL, Bern, und Eidgenössische Forschungsanstalt WSL, Birmensdorf, Conservatoire et Jardin botaniques de la Ville de Genève CJBG, 124 pp.

Spier L., Aptroot A., Herk van K. 2007. Hypotrachyna afrorevoluta (Schilferig schildmos), een over het hoofd gezien algemeen macrolicheen, nieuw voor Nederland. Buxbaumiella 77: 18-20.

Swinscow T. D. V., Krog H. 1988. Macrolichens of East Africa. British Museum (Natural History), London, $390 \mathrm{pp}$.

Wirth V. 1995. Die Flechten Baden-Württenbergs. Teil 1, 2. Verlag E. Ulmer, Stuttgart, 1006 pp.

Zhurbenko M. P., Kukwa M., Oset M. 2009. Roselliniella stereocaulorum (Sordariales, Ascomycota), a new lichenicolous fungus from the Holarctic. Mycotaxon 109: 323-328.

\section{Przyczynek do poznania bioty grzybów zlichenizowanych Polski}

\section{Streszczenie}

Artykuł prezentuje dane dotyczące występowania pięciu taksonów grzybów zlichenizowanych na obszarze Polski. Hypotrachyna afrorevoluta, Lecanora quercicola, Rhizocarpon superficiale i Strigula ziziphi są gatunkami nowymi dla Polski. Spośród nich Strigula ziziphi została stwierdzona jako gatunek nowy dla Europy Środkowej, natomiast Hypotrachyna afrorevoluta jest taksonem nowym dla Karpat. Podano także drugie stanowisko Thelenella muscorum var. octospora z terenu Polski, które jest zarazem pierwszym notowaniem tego porostu dla obszaru polskich Karpat. Stwierdzono po raz pierwszy obecność kwasu hypostiktowego w europejskich (Polska) i południowoamerykańskich (Boliwia) populacjach Rhizocarpon superficiale; substancja ta znana była dotychczas jedynie z północnoamerykańskich okazów tego gatunku. 